\title{
2 | Social movements and rights claims: the case of action groups in the Niger Delta
}

\author{
EGHOSA E. OSAGHAE
}

Several factors have made human rights one of the defining elements of post-cold-war globalization. They include the contradictions of globalization itself, arising from the cross-pressures of closure and openness, exclusion and inclusion, localism and globalism, sameness and difference, and equality and inequality, as well as democratization and liberalization, all of which have accentuated the contestations over state ownership, power relations and citizenship, and have led, in many cases, to protracted and violent conflicts and wars. These have mostly involved marginalized, previously excluded and oppressed groups - 'minorities at risk' (Gurr 1993), indigenous peoples, women's and youth groups, refugees, illegal immigrants, etc. - that have seized the momentum offered by global trends conducive to 'struggles from below' to seek redress of various forms that typically have to do with equal citizenship, equitable power relations and self-determination. The main weapons of struggle are human rights, whose perceived emancipatory and empowering attributes have drawn equity- and justice-seeking groups to them. The very notion that people have rights that entitle them to protection, equality, development and self-determination is enough reason to take the risks of struggling in mostly non-systemic ways.

The foregoing provides the context for analysing the proliferation of what have variously been characterized as 'new grassroots stirrings', 'new social movements' and 'action groups' (Melluci 1985; Cohen 1985; Wignaraja 1993; Haynes 1997). The history of social movements generally revolves around popular, bottom-up and grassroots struggles and resistance by groups under oppressive and unjust regimes as they seek redress and more equitable power configurations. According to a recent definition, social movements 'are usually understood to be collective challenges mounted by relatively marginal groups against powerful elites and dominant ideologies' (Medearis 2005: 54).

For fairly obvious reasons that have to do with long histories of external meddlesomeness (including colonialism and (neo)imperialism), bad governance, oppression, exclusion, poverty, conflict, war, scarcity of resources 
and, more recently, huge foreign debt and state decline or collapse, the bulk of these movements have been in the Third World and Africa (see Sall 2004). The increased global salience of the politics of difference, as well as of issues of citizenship, environmental justice, gender equity, youth empowerment, local political autonomy and resource control, has been a reinforcing factor in the evolving scenarios. The situation in the oil-rich Niger Delta region of Nigeria, which has witnessed an unparalleled prevalence of uprisings by aggrieved minority groups that has transformed the struggles from accommodation-seeking nationalism to self-determination nationalism (Osaghae 2001), represents one of the prototypical and paradigmatic cases of the evolving trends and patterns of new social movements in Africa.

In the case of the Niger Delta (and perhaps other similar African and Third World situations), where sub-national governmental units, specifically state and local governments, have also played leading roles in articulating the populist grievances and demands for equity and justice associated with social movements, and have even been involved in 'hijacked' might be a better word - grassroots mass organization and struggles, it is necessary to further distinguish social movements as non-governmental organizations that are autonomous of the state and its agencies. Indeed, being by their nature against the status quo, social movements cannot ordinarily be aligned with the very system they seek to overthrow, of which sub-national governments that exert various forms of control over instruments of state coercion, including the police, are an integral part. Thus, following Osadolor (2004: 35), action groups in the Niger Delta may be regarded as

resistance movements [which] emerged ... with an ideology based on the principle of self-determination as a driving force for ethnic autonomy. Such movements were the expressed actions taken by the various ethnic nationalities to make their formal declarations and issuance of Bills of Rights in demand for freedom, access to basic needs and resources, protection from environmental pollution, and equal participation in the polity.

In this chapter, I want to examine how the various claims to and demands for rights have enabled and shaped the range of equity- and justice-seeking social movements that have emerged in the Niger Delta; the key point, of course, being that claims to rights are fundamental to the logic and coherence of social movements.

The chapter is in three sections. The first sets the conceptual and 
analytical frame by elaborating on the rights-social movements nexus. This is followed by a discussion of the historical and conceptual location of the Niger Delta. The rest of the chapter interrogates the contexts of relative deprivation, rights denial and injustice within which social movements have emerged in the Niger Delta region. A major objective is to explain why the social movements have been largely ethnic and most recently generational, and to analyse the dynamics and outcomes of the rights struggles waged by the various social movements.

\section{Setting the framework: rights and social movements}

The coherence of social movements is highly dependent on the ability of members to forge common interests, goals and strategies. Human rights tend to be fundamental to these interests and strategies because, on the one hand, allegations and perceptions of discrimination, exclusion, oppression, injustice, domination and exploitation, which all arise from denials and violations of human rights, underlie the emergence of social movements. On the other hand, notwithstanding the character of the struggle waged by members of the movement, whether it be war, violent conflict, riots or protests and the like, the bottom line of social movements is the demand for rights which they believe can be most meaningfully enjoyed when extant (oppressive) social relations are transformed. This makes social movements essentially anti-status-quo (Cohen 1985). According to Touraine (1985: 749), social movements have actors

involved in social conflict, whose goals and strategies have a social coherence and rationality of their own. [Their functions] cannot be understood within the logic of the existing institutional order, since their overriding function is precisely to challenge that logic and transform the social relations which it mirrors and reinforces.

Medearis (2005: 54) makes a similar point:

And acting as they do, in societies characterized by significant inequalities of power, [social movements] face systematic barriers to democratic inclusion for themselves and their arguments. In addition to their weak social positions, they are almost always bearers of ideas that are uncongenial to prevalent institutions and practices. (See also Tarrow 1998)

In these struggles, human rights provide the necessary justificatory and organizing principles that give coherence to the movements. The conception of rights as existential and, more specifically, claims to (denied) rights are central to understanding the origins and activities of the action groups 